\title{
PENGARUH IMAGERY TRAINING TERHADAP HASIL PUKULAN PARKING DAN GATE-IN WOODBALL DI UKM WOODBALL UPI
}

\author{
Ikhwan Maolana Ibrahim Iman, Nur Indri Rahayu, Kuston Sultoni \\ Program Studi Ilmu Keolahragaan \\ Departemen Pendidikan Kesehatan dan Rekreasi \\ Fakultas Pendidikan Olahraga dan Kesehatan \\ Universitas Pendidikan Indonesia \\ Jalan Dr. Setiabudhi no.229 Bandung \\ Ikhwan.maolana@student.upi.edu
}

\begin{abstract}
Abstrak
Penelitian ini bertujuan untuk mengetahui pengaruh imgery training terhadap hasil pukulan parking dan gate-in Woodball di UKM Woodball UPI. Pada Eksperimen ini sampel yang berjumlah 12 orang akan diberikan perlakuan lalu dilihat perbedaan setelahnya, sampel adalah anggota woodball yang baru melakukan latihan (pemula), terdapat 4 putera dan 8 puteri, kemudian sampel dibagi kedalam 2 kelompok (masingmasing 2 putera 4 puteri) yaitu kelompok eksperimen dan kelompok kontrol. Kedua kelompok tersebut sama-sama melakukan latihan selama 18 pertemuan, dan untuk kelompok eksperimen diberikan perlakuan berupa latihan imajeri. Instrumen yang digunakan mengadopsi Tes keterampilan Pukulan Parking dan Gate-in untuk pemula (Putu Citra \& Sukadiyanto, 2015). Teknik analisis data yang digunakan adalah Paired Sample t-test. Hasil dari penelitian ini terdapat pengaruh yang signifikan pada kelompok eksperimen dan tidak terdapat pengaruh yang signifikan pada kelompok kontrol. Kesimpulannya latihan imajeri memberikan pengaruh yang signifikan terhadap hasil pukulan pariking dan gate-in woodball di UKM Woodball UPI. Untuk penelitian selanjutnya alangkah lebih baik apabila jumlah sampel lebih banyak.
\end{abstract}

Kata kunci: Woodball, imagery training, pukulan, parking, gate-in

\section{PENDAHULUAN}

Olahraga Woodball merupakan olahraga yang baru-baru ini sedang berkembang. Sama seperti olahraga pada umumnya Woodball juga memerlukan kemampuan dasar yaitu teknik, fisik, taktik dan mental. Keempat hal tersebut saling berkaitan dan saling mendukung satu sama lain dan harus dilatih agar dapat mencapai prestasi yang maksimal. Seperti yang diungkapkan oleh Harsono (1988) bahwa ada empat aspek latihan yang perlu diperhatikan dan dilatih secara seksama oleh atlet yaitu (a) latihan fisik, (b) latihan teknik (c) latihan taktik, dan (d) latihan mental.

Penting bagi seorang atlet Woodball untuk menguasai teknik dasar pukulan Woodball, salahsatunya yaitu pukulan parking dan gate-in. Pukulan parking atau gate-in bisa sangat menentukan keberhasilan dalam menyelesaikan sebuah fairaway dalam permainan, karena pukulan ini biasanya dilakukan untuk mengarahkan bola langsung masuk kedalam gate atau mengarahkan bola supaya bisa mudah masuk kedalam gate. 
Namun meskipun telah memiliki teknik pukulan yang baik terkadang seorang pemain Woodball tidak selalu bisa memasukan bola dengan mulus kedalam gate, karena ada faktor penentu lain yang juga harus dikuasai oleh pemain Woodball yaitu faktor mental. Salah satunya adalah tingkat kecemasan (Agustiar \& Sultoni, 2016). Olahraga Woodball memerlukan tingkat konsentrasi dan ketenangan yang tinggi, terkadang ketika seorang pemain akan memasukan bola kedalam gawang, dirinya bisa saja diliputi oleh perasaan ragu dan takut, hal tersebutlah yang sering menyebabkan kegagalan seorang pemain Woodball ketika melakukan sebuah pukulan. Untuk menghilangkan hal tersebut caranya adalah dengan melalui latihan mental.

Meskipun aspek mental menjadi hal yang penting bagi seorang atlet, namun pada saat di lapangan ternyata latihan mental belum sepenuhnya dilakukan oleh para pelatih, sebagaimana yang diungkapkan Komarudin (2015) berdasarkan hasil wawancara dan pengamatannya dengan para pelatih cabang olahraga bahwa latihan keterampilan mental belum dilakukan secara seksama dan spesifik dalam proses latihan.

Berdasarkan kenyataan yang ada dilapangan dan dengan melihat kondisi yang ada, dirasa perlu adanya sebuah penelitian yang menjadi bukti empiris bahwa latihan mental dapat meningkatkan kualitas seorang atlet, sehingga dari situ bisa menjadi sebuah referensi bagi para pelatih sehingga mereka mulai melakukan latihan mental untuk para atlet secara seksama.

Salah satu metode yang dapat digunakan dalam latihan mental adalah melalui metode imagery training. Imagery training yaitu latihan dengan membayangkan, memikirkan atau menggambarkan situasi atau gerakan-gerakan tertentu. Imajeri mental adalah serangkaian aktivitas membayangkan atau memunculkan kembali dalam pikiran suatu obyek, peristiwa atau pengalaman gerak yang benar dan telah disimpan dalam ingatan (Blischke, 1999; Finke dalam Suharnan, 2000; Vedelli, 1985; Nurfalah et. al., 2016).

Imagery sangat bermanfaat untuk meningkatkan kemampuan atlet, salahsatunya untuk penguasaan keterampilan gerak olahraga, penguasaan strategi yang akan digunakan dalam pertandingan, mempersiapkan untuk tampil percaya diri, meningkatkan keterampilan interpersonal, dan mengendalikan gejala-gejala psikologis, konsentrasi, memperbaiki kesalahan, bahkan sangat bermanfaat mempercepat pemulihan dari cidera (Komarudin, 2015).

Selain secara langsung mempengaruhi peningkatan keterampilan gerak dan penampilan olahraga, imagery mental juga berkorelasi positif dengan pengembangan aspek-aspek mental yang dapat memoderatori peningkatan keterampilan motorik, seperti kepercyaan diri, motivasi dan kecemasan Weinberg (Hidayat, 2010).

Pelatihan imajeri dilapangan bukan berarti latihan ini dapat menggantikan latihan yang tampak nyata. Ada alasan lain mengapa latihan imajeri sangat penting dilakukan sebagai pelengkap latihan yang nyata yaitu: konseptualisasi keterampilan gerak yang akan dipelajari secara imajeri, secara tidak langsung mengasah kemampuan kognitif dan kemampuan seseorang untuk berfikir.

Dari semua pernyataan tersebut , menunjukan bahwa imagery memberikan dampak positif terhadap perkembangan mental dan peningkatan performa atlet. Dengan merujuk pada acuan ini, tentunya jika proses pembayangan tepat serta treatment yang akan diberikannya sesuai dan tepat sasaran, maka peneliti ingin mengetahui apakah mental imagery dapat memberikan pengaruh yang signifikan untuk meningkatkan keterampilan pukulan parking dan gate-in pada Woodball.

\section{METODE}

Metode penelitian yang digunakan pada penelitian ini adalah kuantitatif dengan pendekatan eksperimen dengan intact grpup Comparison design. Terdapat satu kelompok yang dibagi kedalam dua grup yaitu eksperimen 
dan kontrol. Kedua grup tersebut diberikan latihan selama satu bulan, berbeda dengan grup kontrol yang hanya melakukan latihan saja, grup eksperimen selain melakukan latihan mereka diberika treatment berupa imagery training.

Populasi pada penelitian kali ini yaitu merupaka anggota dari UKM Woodball UPI yang berjumlah 20 orang. Teknik pengambilan sampel yang digunakan adalah dengan cara purposif. Purposive sampling adalah teknik penentuan sampel dengan pertimbangan tertentu (Sugiyono 2010, hlm. 124), hal tersebut dilakukan agar peneliti bisa mendapatkan karakteristik sampel yang sama.

Sampel yang diambil berjumlah 12 orang yang terdiri dari 4 orang putera dan 8 orang puteri.

Sampel tersebut dipilih atas beberapa pertimbangan diantaranya adalah merupakan pemula dan baru melakukan latihan Woodball selain itu sampel juga belum pernah mengikuti kejuaraan Woodball baik ditingkat regional maupun nasional.

Instrumen yang digunakan pada penelitian kali ini adalah tes keterampilan pukulan parking dan gate-in untuk pemula. Setiap sampel akan melakukan tiga pukulan dengan setiap pukulannya berada pada titik yang berbeda. Pertama-tama setiap sampel harus menyelesaikan pukulan yang pertama hingga bola masuk melewati gate, barulah setelah itu mereka bisa melanjutkan ke pukulan berikutnya. Setelah menyelesaikan ketiga pukulan tersebut, kemudian hasilnya diakumulasikan.

Adapun alat yang diperlukan dalam pengambilan data yakni; 1) Stopwatch 2) Mallet 3) Bola Woodball 4) Gate 5) Score card 6) Alat tulis.

\section{HASIL DAN PEMBAHASAN}

Pertama-tama kedua grup tersebut melakukan pretes,t setelah itu mereka melakukan latihan selama 1 bulan dengan jumlah totalnya 18 kali pertemuan. Kemudian barulah sampel melakukan posttest untuk melihat apakah terjadi perubahan yang signifikan setelah melakukan latihan dan diberikan treatment.

Hasil dari pretest dan posttest untuk kelompok eksperimen dan kontrol dapat dilihat pada Gambar. 1 dan Gambar. 2

Pada gambar. 1 dapat dilihat jika kelompok eksperimen secara keseluruhan setelah melakukan latihan yang dibarengi dengan treatment berupa latihan imajeri sampel mengalami peningkatan, dan untuk kelompok kontrol yang hanya melakukan latihan saja sebagian besar dari mereka mengalami peningkatan walau hanya 1 poin.

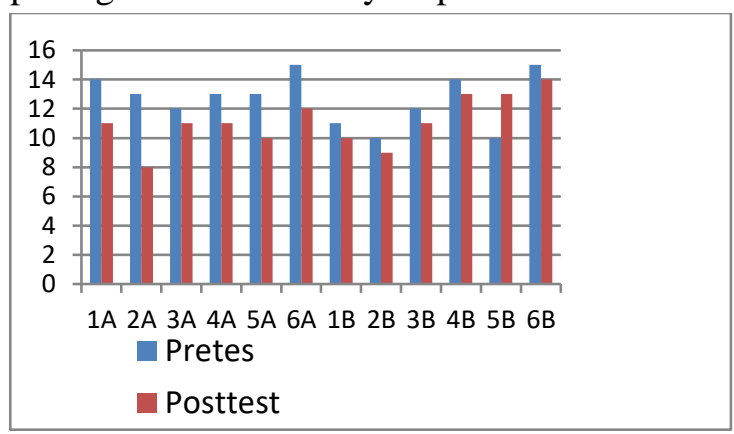

Gambar.1 Hasil Pretest-Posttest Kelompok Eksperimen dan Kontrol

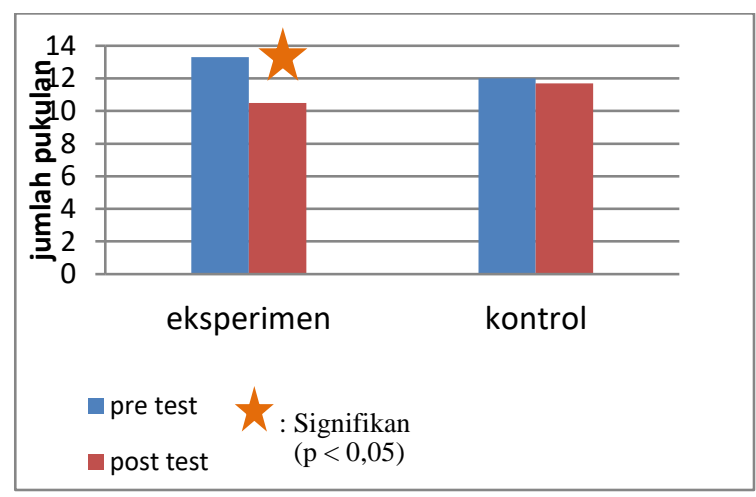

Gambar. 2 Hasil Rata-rata Pretest-Posttest Kelompok Eksperimen dan Kelompok Kontrol

Pada Gambar. 2 dapat dilihat bahwa terjadi perbedaan yang signifikan pada kelompok eksperimen dengan nilai $\mathrm{p}<0,05$, sedangkan pada kelompok kontrol tidak terjadi perbedaan yang signifikan.

Nilai rata-rata jumlah pukulan pada saat pretes kelompok eksperimen yaitu 13,3 dan jumlah rata-rata posttestnya 10,50 . Sedangkan 
nilai rata-rata jumlah pukulan pada saat pretes kelompok kontrol yaitu 12 dan jumlah rata-rata posttestnya 11,6.

Tabel. 1 Pengujian Hipotesis

\begin{tabular}{|l|l|l|l|}
\hline kelompok & t-hitung & Sig & Keputusan \\
\hline Eksperimen & 5,222 & 0,003 & H0 Ditolak \\
Kontrol & 0,500 & 0,683 & H0 Diterima \\
\hline
\end{tabular}

Pada Tabel. 1 dapat dilihat nilai $t$ kelompok eksperimen 5,222 dan kelompok kontrol 0,500. Nilai signifikansi kelompok eksperimen 0,003 hal ini berarti bahwa $\mathrm{p}=<$ 0,05 maka H0 Ditolak dan terdapat perbedaan yang signifikan. Sedangkan nilai signifikansi kelompok kontrol yaitu $0,683, \mathrm{p}=>0,683$, maka H0 Diterima dan tidak terdapat perbedaan yang signifikan.

Berdasarkan hasil penelitian ini latihan imajeri membantu seorang atlet dalam meningkatkan kemampuan pukulan parking dan gate-in, hal tersebut dibuktikan dari hasil pretest dan posttest pada kelompok eksperimen yang memiliki perbedaan yang signifikan, sedangkan pada kelompok kontrol yang hanya melakukan latihan saja tanpa melakukan latihan imajeri tidak terdapat perbedaan yang signifikan.

Latihan imajeri akan membantu seseorang lebih cepat menguasai sebuah keterampilan, dengan cara memvisualisasikan gerakan-gerakan didalam pikirannya maka secara tidak langsung orang tersebut terus menstimulasi otaknya untuk melakukan sebuah pengalaman gerak, dengan begitu akan lebih memudahkan orang tersebut ketika mempraktekan/melakukan gerakan yang dia bayangkan. Hal tersebut dikenal dengan symbolic learning theory. Menurut Apruebo (Komarudin 2015) teori ini memfasilitasi performa atlet dengan cara atlet membuat kode gerak atau perencanaan gerak ke dalam komponen simbol yang menyebabkan atlet dapat melakukan pola gerak lebih mudah, lebih familier dan lebih otomatis.

Selain untuk mempelajari sebuah keterampilan, imajeri juga dapat membantu meningkatkan kemampuan konsentrasi dan fokus bagi orang yang melakukannya. Ketika atlet melakukan imajeri dirinya diharuskan tetap fokus untuk gerakan-gerakan yang dia bayangkan sehingga hal tersebut akan membuat atlet tersebut akan meningkatkan kemampuan konsentrasinya. Sebagaimana yang diungkapkan Murphy \& Jowdy bahwa pelatihan imajeri dapat meningkatkan kesadaran diri, memfasilitasi penguasaan dan pemeliharaan keterampilan, membangun kepercayaan diri, mengontrol emosi dan dipercaya dapat meningkatkan strategi persiapan untuk meningkatkan performanya (Komarudin 2015, hlm. 90)

\section{KESIMPULAN}

Mental merupakan salahsatu hal yang harus dilatihkan kepada seorang atlet, karena seperti yang kita ketahui factor mental dapat mempengaruhi faktor-faktor lain seperti fisik, teknik dan taktik. Latihan imajeri dapat membantu seseorang untuk dalam meningkatkan keterampilan selain itu dengan melakukan latihan imajeri fokus dan konsentrasi dari seorang atlet dapat terasah dan meningkatkan kepercayaan diri atlet tersebut

Berdasarkan hasil pengolahan dan analisis data, setelah peneliti melakukan pengukuran melalui pretes dan posttest ternyata perlakuan yang diberikan kepada kelompok eksperimen berupa latihan imajeri dapat memberikan pengaruh yang signifikan terhadap peningkatan keterampilan atlet, sedangkan pada kelompok kontrol yang hanya melakukan latihan biasa tanpa melakukan latihan imajeri tidak ada peningkatan yang signifikan.

Pada penelitian kali ini berdasarkan hasil temuan peneliti menyimpulkan bahwa Terdapat pengaruh yang signifikan imagery training kelompok yang diberikan perlakuan (kelompok eksperimen) dengan kelompok yang tidak diberikan perlakuan (kelompok kontrol) terhadap hasil pukulan parking dan gate-in Woodball di UKM Woodball UPI 


\section{DAFTAR PUSTAKA}

Agustiar, O., \& Sultoni, K. (2016). Hubungan Tingkat Kecemasan dengan Hasil Pukulan Gate-In pada Olahraga Woodball. Jurnal Terapan Ilmu Keolahragaan, 1(2), 64-69.

Citra, P., \& Sukadiyanto. (2015). Pengembangan Tes Keterampilan Olahraga Woodball Untuk Pemula. Jurnal Keolahragaan, 3(2), 228-240.

Firmansyah, H. (2011). Perbedaan Pengaruh Latihan Imagery Dan Tanpa Latihan Imagery Terhadap Keterampilan Senam Dan Kepercayaan Diri Atlet. Jurnal Olahraga Prestasi, 7(1), 1-10.

Gunarsa, S. D., Satiadarma, M. P., \& Hardjolukito, M. (1996). Psikologi Olahraga Teori dan Praktik. Jakarta: PT. BPK Gunung Mulia.

Harsono. (1988). coaching dan aspek-aspek psikologis dalam coaching. Bandung: CV Irawan.

Hidayat, Y. (2010). Psikologi Olahraga. Bandung: CV. Bintang Warli Artika.

Komarudin. (2015). Psikologi Olahraga. Bandung: PT. Remaja Rosdakarya.

Kriswantoro. (2011). Teknik Dasar Bermain Woodball. Semarang: Indonesia Woodball Association.

Nurfalah, R. T., Ugelta, S., \& Imanudin, I. (2016). Pengaruh Imajery Training terhadap Keterampilan Hasil Shooting Sepak Bola di SSB Java Putra Yudha. Jurnal Terapan Ilmu Keolahragaan, 1(1), 40-44.

Smith, D., \& Holmes, P. (2004). The Effect of Imagery Modality on Golf Putting Performance. JOURNAL OF SPORT \& EXERCISE PSYCHOLOGY, 26, 385-395.

Soetrisno. (2011). Mari Bermain Woodball (Lets Play woodball). Semarang: Indonesia Woodball Association.

Sugiyono. (2010). Metode Penelitian Kuantitatif Kualitatif dan $R$ \& D. Bandung: ALFABET. 